\title{
A window of opportunity: declining rates of hepatitis $B$ virus infection among injection drug users in Rio de Janeiro, and prospects for targeted hepatitis B vaccination
}

\author{
Sabrina A. N. Oliveira, ${ }^{1}$ Mariana A. Hacker, ${ }^{2}$ M. Lourdes A. Oliveira, ${ }^{1}$ \\ Clara F. T. Yoshida, ${ }^{1}$ Paulo R. Telles, ${ }^{3}$ and Francisco I. Bastos ${ }^{2}$
}

Suggested citation

Oliveira SAN, Hacker MA, Oliveira MLA, Yoshida CFT, Telles PR, Bastos FI. A window of opportunity: declining rates of hepatitis $B$ virus infection among injection drug users in Rio de Janeiro, and prospects for targeted hepatitis B vaccination. Rev Panam Salud Publica. 2005;18(4/5):271-7.

ABSTRACT

Objectives. To measure hepatitis B virus (HBV) infection rates among injection drug users in Rio de Janeiro, Brazil, and to report their knowledge of and attitudes toward hepatitis and $H B V$ vaccination.

Methods. 609 injection drug users recruited in Rio de Janeiro between 1999 and 2001 answered a questionnaire and were tested for hepatitis B and other blood-borne infections. Questions covered sociodemographic information, alcohol and illicit drug consumption, drug injection and sexual practices, medical history, and knowledge about HIV , AIDS and viral hepatitis. Results. The prevalence of HBV infection was $27.1 \%$, with $3.4 \%$ of the sample positive for $\mathrm{Hbs} \mathrm{Ag}$ (active infection) and $0.8 \%$ positive for anti-HBs (indicating previous HBV vaccination). Most interviewees (81.3\%) were aware of at least one form of viral hepatitis and received information from many different sources. In agreement with laboratory findings, $96.7 \%$ of the interviewees stated they had never been vaccinated against hepatitis $B$, but almost all unvaccinated interviewees $(97.8 \%)$ said they would volunteer to be vaccinated if HBV vaccination were available.

Conclusions. Few of the injection drug users surveyed had ever been vaccinated against $H B V$. Although most were aware of the risks posed by viral hepatitis, this awareness seldom translated into consistent behavioral change. The participants' willingness to be vaccinated against HBV suggests that the implementation of vaccination for this population may help decrease rates of hepatitis $B$ infection.

Key words Brazil; hepatitis B virus; injection drug users; vaccination.

The National Reference Laboratory for Viral Hepatitis, Department of Virology, Oswaldo Cruz Foundation, Rio de Janeiro, Brazil; Send correspondence and reprint requests to Sabrina A. N. Oliveira, The National Reference Laboratory for Viral Hepatitis, Department of Virology, Oswaldo Cruz Foundation (FIOCRUZ), Pavilhão Rocha Lima, 5th floor, Av. Brasil 4365, Manguinhos, 21045-900, Rio de Janeiro, Brazil: telephone: (55) 21 2598 4425; fax: (55) 212270 6397: e-mail: salberti@ ioc.fiocruz.br
Hepatitis B is a global public health concern. The hepatitis B virus (HBV) is transmitted through unprotected sexual intercourse and contact with con-

\footnotetext{
2 Department of Health Information, Oswaldo Cruz Foundation, Rio de Janeiro, Brazil.

3 Harm Reduction Initiative, State University of Rio de Janeiro, Rio de Janeiro, Brazil.
}

taminated blood or blood derivatives. According to a recent estimate, of 2 billion people infected with HBV worldwide, approximately 350 million people are chronically infected with HBV $(1,2)$.

In Brazil, 2 million people are estimated to be chronically infected with 
HBV, with substantial differences between different Brazilian regions (3). In the southern region endemicity for hepatitis B is low, whereas clusters of high endemicity have been found in the Amazonian basin (north) and some areas of the states of Santa Catarina (south) and Espírito Santo (southeast). Most of the southeastern region (Brazil's most industrialized region) as well the central-western and northeastern regions are medium endemicity areas (3).

Because of their unhygienic injection habits and inconsistent use of condoms, injection drug users (IDUs) constitute a major at-risk population and a key source of new infections to the non-injecting population (4-9). However, epidemiological studies of hepatitis B among IDUs in Brazil are scarce. Carvalho et al. (1996) found high infection rates for HBV (with a prevalence of 75\%) among IDUs from Santos (state of São Paulo), in a context of frequent injection cocaine use and a high prevalence of sharing injection equipment and having unprotected sex with multiple partners (10). Another study of IDUs recruited in the drug scene and at drug treatment centers in Rio de Janeiro in 1994 to 1996 found a $55.8 \%$ prevalence for HBV infection and a $7.8 \%$ prevalence of active infection (HbsAg) (11). A third study in 1998 involved drug users (most of them non-injecting users) seeking care in drug treatment centers from Rio de Janeiro, and found a point prevalence of $14.7 \%$ for HBV infection (12).

The World Health Organization (WHO) Drug Injection Study Phase II is a multicity study of injection drug use in the United States, Thailand, Greece, Colombia, Brazil, Nigeria, China, Argentina, Vietnam, India, Malaysia, Kenya, Belarus, the Russian Federation and the Ukraine (13).

It was designed to provide policyand decision-makers with comprehensive, reliable information to develop interventions for injection drug users. The study assessed the health consequences of injection drug use by conducting rapid assessments in the field and by surveying behavior and the seroprevalence of human immunode- ficiency virus (HIV), HBV and hepatitis $\mathrm{C}$ virus among injection drug users. The present paper analyzes data from the WHO Multicity Study in order to measure HBV infection rates and to collect sociodemographic and behavioral data essential for developing HBV vaccination efforts in Brazil.

A full list of all collaborative investigators is presented in the main reports of the study (14). The authors alone are responsible for the views expressed in this paper, which do not necessarily represent those of the other investigators participating in the WHO Drug Injection Study Phase II or the views or policy of the World Health Organization.

\section{METHODS}

Volunteers were recruited from October 1999 to December 2001 from different Rio de Janeiro communities. The targeted communities were identified by in-depth interviews with key informants and drug users from different communities and with focus groups, in accordance with WHO guidelines (15). A team of outreach workers and a mobile unit were used to recruit potential interviewees and to bring them to the assessment center, located downtown. Efforts were made to recruit people that were as representative of the diversity of Rio de Janeiro's social geography as possible.

Outreach workers were recruited in the same communities they worked in. Their sociodemographic profile was similar to that of the interviewees themselves, with whom they shared many aspects of their habits and mores. None of the drug users refused to answer the questionnaire or to have a blood test. This can probably be attributed to the fact that participation in the project resulted in referral to preventive and treatment services, as well as to the deep level of local community trust in the outreach workers.

In the present paper, current IDUs were defined as "someone injecting an illicit drug at least once in the 6 months before interview" and an exIDU as "someone who ever injected il- licit drugs, but not in the last 6 months"(15). No a priori minimum injection frequency was set as an inclusion criterion.

After they had read and signed an informed consent form, 609 active and ex-IDUs were interviewed and donated $30 \mathrm{~mL}$ of whole blood. The standard questionnaire, developed and piloted by the WHO collaborative group, (15) assessed sociodemographic information, alcohol and illicit drug consumption, drug injection and sexual practices, medical history, and knowledge about HIV, AIDS and viral hepatitis (16). Sociodemographic and behavioral data were entered into an electronic form written in Epi-info 6.2 and developed by the Brazilian team in accordance with WHO's master codes and electronic framework.

Blood samples were processed by two laboratories (AIDS and Molecular Immunology Laboratory and The National Reference Center for Viral Hepatitis) located at the Oswaldo Cruz Foundation in Rio de Janeiro. The tests used to detect HBV were based on enzyme immunoassays for the serological markers HBsAg, anti-HBc and anti-HBs.

\section{RESULTS}

As shown in Table 1, most of the interviewees were male $(91.5 \%)$, and mean age was 32 years. The distribution of our sample by race and ethnicity was about even between whites $(48.6 \%)$ and nonwhites $(51.4 \%$, comprising blacks and mulattos). Most interviewees $(64.2 \%)$ were single and roughly half $(45.8 \%)$ of them had only received primary-level schooling (8 years or less of formal education). Almost half of the interviewees $(44.7 \%)$ reported living in someone else's home during the preceding 6 months, and slightly under half of them $(44.5 \%)$ had been in jail or prison.

Most of the interviewees $(58.6 \%)$ reported living below the Brazilian poverty line of US\$ 90.00 per month. About three quarters of them $(76.5 \%)$ reported being formally employed, and $15.8 \%$ were supported by government benefits, student financial aid or some- 
TABLE 1. Sociodemographic characteristics of 609 injection drug users who participated in the WHO Multicity Study, Rio de Janeiro (Brazil), 1999-2001

\begin{tabular}{|c|c|}
\hline Sociodemographic characteristics & $n(\%)$ \\
\hline Mean age (years) & $32.2( \pm 9.8)$ \\
\hline \multicolumn{2}{|l|}{ Sex } \\
\hline Male & $557(91.5)$ \\
\hline Female & $52(8.5)$ \\
\hline \multicolumn{2}{|l|}{ Race } \\
\hline White & $296(48.6)$ \\
\hline Nonwhite & $313(51.4)$ \\
\hline \multicolumn{2}{|l|}{ Marital status } \\
\hline Legally married/living as married & $158(25.9)$ \\
\hline Widowed/legally separated/divorced & $60(9.9)$ \\
\hline Single & $391(64.2)$ \\
\hline \multicolumn{2}{|l|}{ Years of education } \\
\hline$<8$ years (some primary education) & $279(45.8)$ \\
\hline$\geq 9$ years (complete primary education) & $330(54.2)$ \\
\hline \multicolumn{2}{|l|}{ Monthly income in the preceding 6 months } \\
\hline$\leq 1$ Brazilian minimum wage ${ }^{\mathrm{a}}$ & $357(58.6)$ \\
\hline$>1$ Brazilian minimum wage & $249(40.9)$ \\
\hline No information & $3(0.5)$ \\
\hline \multicolumn{2}{|l|}{ Source of income in the previous 6 months } \\
\hline Regular job & 466 (76.5) \\
\hline Benefits, student financial aid, someone else's income & $96(15.8)$ \\
\hline Illegal activities & $47(7.7)$ \\
\hline \multicolumn{2}{|l|}{ Where did you live in the preceding 6 months? } \\
\hline Owned house, flat or apartment & $133(21.8)$ \\
\hline Rented house, flat or apartment & $87(14.3)$ \\
\hline Someone else's house & $272(44.7)$ \\
\hline Other & $115(18.9)$ \\
\hline No information & $2(0.3)$ \\
\hline \multicolumn{2}{|l|}{ Ever been in jail or prison } \\
\hline Yes & $271(44.5)$ \\
\hline No & $338(55.5)$ \\
\hline
\end{tabular}

${ }^{a}$ Equivalent to approximately US\$ 90.00 .

one else's income. Nearly $8 \%$ had engaged in miscellaneous illegal activities such as prostitution, begging, drug smuggling or theft.

The sample included a small proportion $(17 \%)$ of interviewees who were attending drug treatment programs. Among the drug users with a history of drug injection, $45 \%$ reported having injected at least once in the previous 6 months, and $55 \%$ were considered former injectors (ex-IDUs).

Table 2 shows drug consumption patterns and sexual behaviors of the interviewees. Most interviewees (68.8\%) had never received treatment for drug use. For $85.2 \%$ of the participants, injection was not the primary method of drug consumption; the predominant type of consumption among these users was inhaled cocaine with occasional cocaine injection (data not shown). Among the 257 IDUs who obtained sterile syringes in the preceding 6 months, the two most frequent sources were pharmacies $(75.5 \%)$ and needle-exchange programs (30.7\%).

A small proportion of interviewees admitted having knowingly engaged in risk behaviors. For example, $4.6 \%$ reported sharing their injection equipment with HIV-positive individuals, and $1.3 \%$ shared equipment with hepatitis-positive individuals.

Nearly $37 \%$ of the active injectors reported needle sharing in the preceding 6 months, whereas $63.4 \%$ reported they did not give, lend, rent or sell their needles or syringes to others. Over three quarters of the interviewees $(78.4 \%)$ reported that they had never helped someone inject for the first time.

Most interviewees had been engaged in a variety of sexual relation- ships, and most had more than one principal sexual partner. Reported condom use was very low. Half (49.6\%) of the interviewees reported having had only one principal partner in the previous 6 months, and $5.7 \%$ reported having more than one partner they consider "principal" in the same period. Slightly less than half $(42.0 \%)$ of the interviewees reported more than two sexual intercourses per week with their principal partners, most of the times $(63.0 \%)$ without wearing a condom.

Almost half $(46.5 \%)$ of the interviewees reported having more than two occasional partners in the preceding 6 months, and one third (31.6\%) of them reported never using a condom with their occasional partners. Although the proportion of interviewees who reported having been engaged in commercial sex in the preceding 6 months was relatively low (10.5\%), the proportion of those who reported never using a condom in these relationships was quite high (39.4\%).

Slightly more than one third of the men interviewed $(34.5 \%)$ reported having sexual intercourse with another man in the preceding 5 years, whereas this proportion was $16.7 \%$ for same-sex intercourse during the preceding 6 months. Half $(51 \%)$ of these interviewees never used a condom with their same-sex partners.

As shown in Table 3, most interviewees $(70.4 \%)$ self-described their current health as excellent or good. This is in stark contrast to frequent reports of different illnesses and ailments: almost half $(47.3 \%)$ of the interviewees mentioned having had gonorrhea, and many had had pneumonia $(31.0 \%)$, oral candidiasis $(10.5 \%)$, hepatitis $(10.0 \%)$ or syphilis $(8.2 \%)$. Other infections and diseases were mentioned by more than one third of the interviewees $(36.1 \%)$, including cirrhosis, genital herpes, endocarditis, chlamydia infection and malaria. Almost one third of the interviewees $(31.7 \%)$ reported abscesses at injection sites, and $12.5 \%$ mentioned collapsed veins.

The overall prevalence of HBV infection was $27.1 \%$, with a prevalence of positivity for HBsAg (active infec- 
TABLE 2. Drug use and risk behaviors in 609 injection drug users who participated in the WHO Multicity Study, Rio de Janeiro (Brazil), 1999-2001

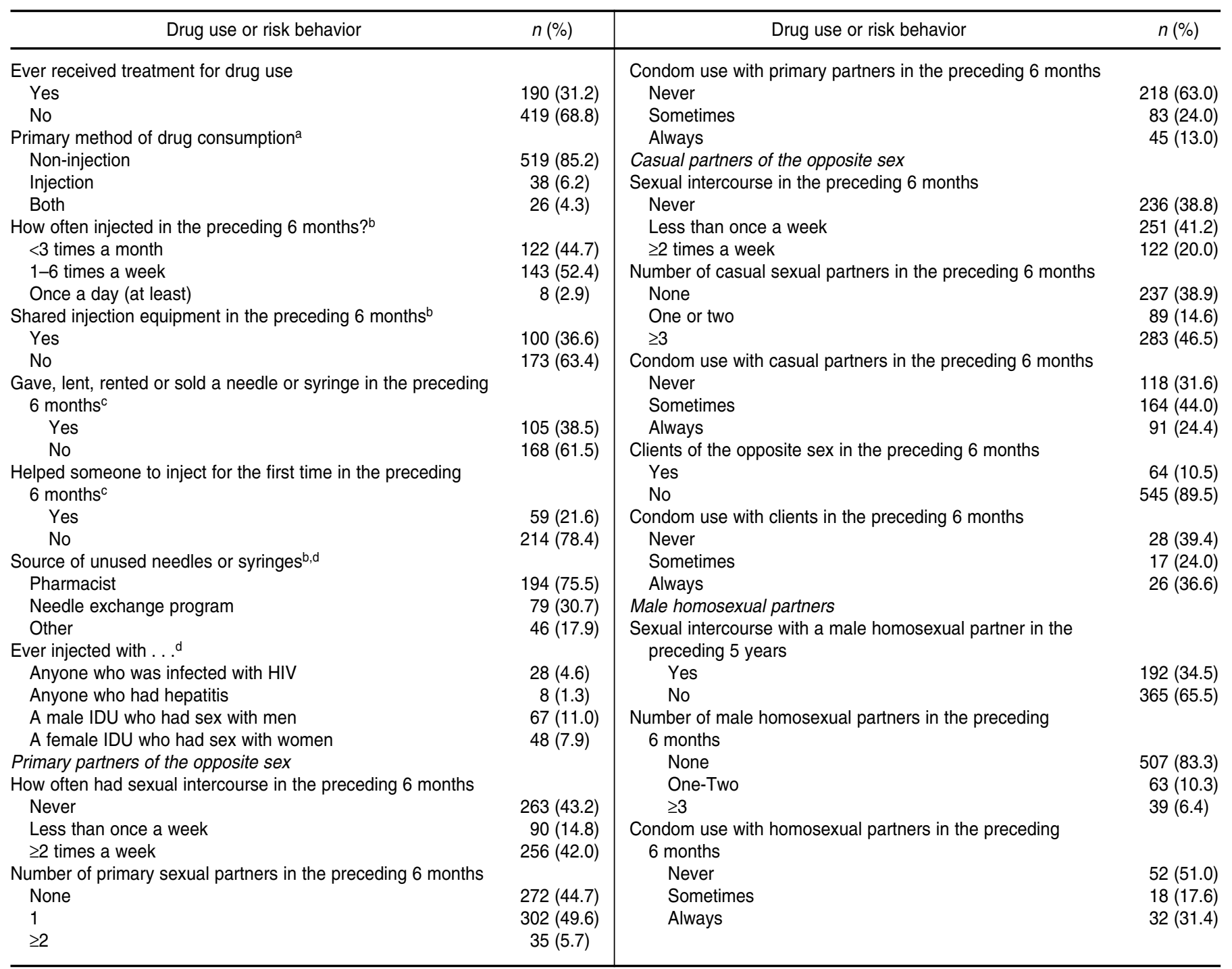

${ }^{a}$ Did not total $100 \%$ because of missing or unclear information.

${ }^{\mathrm{b}}$ Among current IDUs (those who had been injecting during the preceding 6 months, $n=273$ ).

${ }^{c}$ Among those who injected with used needles or syringes in the preceding 6 months, $n=257$.

${ }^{\mathrm{d}}$ Multiple answers allowed.

tion) of $3.4 \%$ and a prevalence of antiHBs positivity (indicating previous HBV vaccination) of $0.8 \%$.

More than two thirds (76.5\%) of the interviewees said they were concerned about getting hepatitis, and $81.3 \%$ said they knew of at least one type of hepatitis. Almost all interviewees (96.7\%) stated they had never received a hepatitis $B$ vaccination, but again, almost all of the unvaccinated individuals $(97.8 \%)$ said they would volunteer to be vaccinated if $\mathrm{HBV}$ vaccination were offered.

The mass media were the most frequent source of information about hepatitis, according to about half (49.3\%) of the interviewees. Other relevant sources included family and friends $(25.0 \%)$, health workers $(22.8 \%)$, needle-exchange programs $(10.3 \%)$ and a variety of sources such as place of work, school, leaflets, and injection partners and buddies (8.4\%).

\section{DISCUSSION}

The sample in the present study consisted mainly of young men. Previous studies have consistently shown that the number of injection drug users in Rio de Janeiro who are women is small, regardless of the time period and sampling strategy (i.e., streetrecruited drug users versus drug users attending treatment centers) $(11,12$, $17,18)$. 
TABLE 3. Medical history, prevalence of hepatitis B seromarkers and knowledge of hepatitis in 609 injection drug users who participated in the WHO Multicity Study, Rio de Janeiro (Brazil), 1999-2001

\begin{tabular}{lc}
\hline \multicolumn{1}{c}{ Medical history } & $n(\%)$ \\
\hline Self-described current health & \\
Excellent/Good & $429(70.4)$ \\
Fair/Poor & $174(28.6)$ \\
No information & $6(1.0)$ \\
History of infections & \\
Pneumonia & $189(31.0)$ \\
Oral candidiasis & $64(10.5)$ \\
Syphilis & $50(8.2)$ \\
Gonorrhea & $288(47.3)$ \\
Hepatitis & $61(10.0)$ \\
Abscesses at an injection site & $193(31.7)$ \\
Collapsed veins & $76(12.5)$ \\
Others & $220(36.1)$ \\
Hepatitis B seromarkers & \\
HBV (HBsAg or anti-HBc) & $165(27.1)$ \\
HbsAg & $21(3.4)$ \\
Anti-HBs & $5(0.8)$ \\
Can you name any type of hepatitis? & \\
Any type (A/B/C) & $495(81.3)$ \\
Cannot name any type & $114(18.7)$ \\
Ever been vaccinated against hepatitis B? & $15(2.5)$ \\
Yes & $589(96.7)$ \\
No & $5(0.8)$ \\
No information & \\
Would accept hepatitis B vaccination if it were offered & \\
Yes & $582(97.8)$ \\
No & $13(2.2)$ \\
Where heard about hepatitis (B/C)a & \\
Newspaper, magazine, radio or TV & $300(49.3)$ \\
Health worker & $139(22.8)$ \\
Needle exchange program & $63(10.3)$ \\
Family or friends & $51(8.4)$ \\
Others & $533(87.5)$ \\
Knows how hepatitis B is transmitted & $14(2.5)$ \\
Don't know & $62(10.0)$ \\
Sharing needles or syringes & $466(76.5)$ \\
Other & $143(23.5)$ \\
Concerned about getting hepatitis B & \\
Yes & \\
No & \\
\hline & \\
\hline &
\end{tabular}

${ }^{a}$ Multiple answers allowed.

${ }^{\mathrm{b}}$ Among those who had not been vaccinated before or refused to answer $(n=595)$.

Another feature of our study population is the adverse combination of unemployment or low wages and low educational level and economic dependence on other people or institutions. These factors make this population especially vulnerable and underserved $(19,20)$.

Interviewees seemed to be aware of the risks associated with hepatitis, but this perception has not been translated consistently into safer behaviors. The risk of harm (including local abscesses and venous lesions) associated with unsafe injection practices such as injection equipment sharing is unacceptably high. The additional burden posed by major infections (e.g., endocarditis and pneumonia) commonly associated with unhygienic injection practices were also of concern among our interviewees.

Condom use was inconsistent irrespective of the nature of sexual partnership. Erratic condom use was reported even when interviewees knew about their partner's positive serosta- tus for HIV or hepatitis. The continuous exposure to sexually transmitted pathogens seems to translate into a high prevalence of sexually transmitted infections such as syphilis and gonorrhea. Infection rates for hepatitis $\mathrm{B}$ in the present study were still high in comparison to other Brazilian populations. For example, a comprehensive multicenter study at a network of Brazilian blood banks found prevalences of $0.9 \%$ and $1.0 \%$ for HBsAg and $5.8 \%$ and $8.3 \%$ for anti-HBc, respectively, in blood donors from the southeastern region and from Brazil overall (21).

This gap between awareness of risk behaviors and behavioral change has been reported for many different conditions and diseases, and was recently highlighted by our team in a paper addressing the inconsistent adoption of safer sex in a cohort of gay men who perceived themselves as vulnerable to HIV infection (22). Perhaps most importantly, only 15 IDUs in our study were actually vaccinated against hepatitis $B$, despite the fact most of them reported they would volunteer to be vaccinated if vaccination were offered.

The present study nevertheless holds some promising findings, and suggests that there may be a window of opportunity for effective interventions. A history of time in jail or prison was reported by $44.5 \%$ of our interviewees, and this represents a decrease in comparison to previous Brazilian studies which reported higher incarceration rates among IDUs $(10,11)$. Imprisonment has been highlighted as a frequent hazard in the career of IDUs (23). The findings of the present study also found a smaller proportion of interviewees who reported engaging in illicit activities such as drug smuggling or theft compared to previous Brazilian studies (10) and other research (24).

The rates of infection by blood-borne viruses in the present study are substantially lower than in other studies of IDUs in Brazil (10, 11), Argentina (25) and the United States $(6,26,27)$. Especially relevant is the low prevalence of active infections, since most infections in this population occur early in the drug injector's career (6). The decline may be attributable to an overall de- 
cline in injection frequencies (along with other factors such as saturation) in comparison to previous data for the same population $(11,18)$. This decline was especially evident among new injectors, as discussed elsewhere (28). Most active and ex-users who participated in the present study never used injection as the primary method of consumption. The reduction in injection frequencies may also help to explain the substantial declines in HIV prevalence (28) and incidence (18), and in hepatitis C prevalence (29) in the present study, compared to previous studies of the Rio de Janeiro population of IDUs.

Our findings suggest that IDUs in Rio de Janeiro may be adopting safer behaviors, possibly influenced by preventive campaigns in the mass media and word-of-mouth advice on safer habits. These changes may be reinforced by sustained efforts through different preventive programs (29). However, the decline should not be viewed with complacency, given the persistently high levels of needle sharing and sexual risk behaviors. Also of concern are the findings that few of our interviewees had been vaccinated for hepatitis B, and that most of them did not translate their apparent apprehensions about hepatitis B into concrete actions.

A concerted effort to integrate and scale up preventive strategies might include health promotion, condom distribution and increased access to sterile equipment, In addition, a targeted HBV vaccination strategy should be implemented, as part of the recently issued Portaria [Directive] number 2080/GM (October 31 2003) (30) of the Brazilian Ministry of Health. This directive states that vulnerable populations (e.g., health care professionals, patients on dialysis, transplantation patients and IDUs, among others) should be preferential targets of initiatives aimed at scaling up hepatitis B vaccination efforts.
Needle-exchange programs and health facilities of the type requested most frequently by IDUs (such as emergency rooms, drug treatment centers and sexually transmitted disease clinics) constitute primary venues for the implementation of innovative vaccination initiatives $(26,31-34)$. Concerted efforts to integrate medical care, psychosocial support and hepatitis B vaccination represent the only true hope against the terrible burden faced by injection drug users and their sexual partners in Brazil and worldwide.

Acknowledgments. The project was partially financed by the World Health Organization (WHO) and CNPq (Brazilian Research Council) through grant 475.668/2003-0. The authors wish to thank Amy Nunn (Harvard School of Public Health) for her contribution in the preparation of the revised manuscript.

\section{REFERENCES}

1. Lai CL, Ratziu V, Yuen MF, Poynard T. Viral hepatitis B. Lancet. 2003; 362(9401):2089-94.

2. World Health Organization. Weekly epidemiological record, 78th year (42): 368-370; 2003. Available from: www.who.int/wer/2003/ en/wer7842.pdf. Accessed 26 May 2004.

3. Brazil, Ministry of Health 2001. Boletim eletrônico epidemiológico Ano 1 Número 2. [Internet site]. Available from: dtr2001.saude. gov.br/svs/pub/boletim_eletronico_epi/ boletim_eletronico_epi_0102.pdf. Accessed 26 May 2004.

4. Scheutz F, Skinhoj P, Mark I. Viral hepatitis among parenteral drug addicts attending a Danish addiction clinic. Scand J Infect Dis. 1983;316(16):139-43.

5. Alter MJ, Coleman PJ, Alexander J, Kramer E, Miller JK, Mandel E, et al. Importance of heterosexual activity in the transmission of hepatitis $B$ and non-A, non-B hepatitis. JAMA. 1989;262(9):1201-05.

6. Garfein RS, Vlahov D, Doherty MG, Nelson KE. Viral infections in short-term injection drug users: the prevalence of the hepatitis $\mathrm{C}$, hepatitis B, human immunodeficiency, and human T-lymphotropic viruses. Am J Public Health. 1996;86(5):655-61.

7. Sulkowski MS, Thomas DL. Viral hepatitis among injection drug users. Viral Hepatitis Rev. 1998;4(4):229-44.
8. Saha MK, Chakrabarti S, Panda S, Naik TN, Manna B, Chatterjee A, et al. Prevalence of HCV \& HBV infection amongst HIV seropositive intravenous drug users \& their noninjecting wives in Manipur, India. Indian J Med Res. 2000;111:37-9.

9. Renwick N, Dukers NHTM, Weverling GJ, Sheldon JA, Schulz TF, Prins M, et al. Risk factors for human herpesvirus 8 infection in a cohort of drug users in The Netherlands, 19851996. J Infect Dis. 2002;185:1808-12.

10. Carvalho HB, Mesquita F, Massad E, Bueno RC, Lopes GT, Ruiz MA, et al. HIV and infections of similar transmission patterns in a drug injectors community of Santos, Brazil. J Acqui Immune Defic Syndr Hum Retrovirol. 1996;12(1):84-92.

11. Oliveira MLA, Bastos FI, Telles PR, Yoshida CFT, Schatzmayr HG, Paetzold U, et al Prevalence and risk factors for $\mathrm{HBV}, \mathrm{HCV}$ and HDV infections. Braz J Med Biol Res. 1999; 32(9):1107-14.

12. Bastos FI, Lowndes CM, Derrico M, CastelloBranco LRC, Carvalho MIL, Oelemann W, et al. Sexual behavior and infection rates for HIV, blood-borne and sexually transmitted infections among patients attending drug treatment centers in Rio de Janeiro, Brazil. Int J. STD AIDS. 2000;11:383-92.

13. WHO (World Health Organization). Drug Injecting Study II, Master Codebook Version
4(1), 2000. Available from: www.who.int/ substance_abuse/activities/en/WHODrug InjectionStudyMasterCodebook.pdf. Accessed 21 July 2005.

14. World Health Organization, Department of Mental Health and Substance Dependence, 2000. A report from the WHO Drug Injection Study Phase II-An international review of rapid assessments conducted on drug use, 2000. Available from: www.who.int/substance abuse/publications/en/rar_review.pdf. Accessed 21 July 2005.

15. WHO (World Health Organization). WHO Drug Injecting Study II-operations manual, version 4, September 28th, 2000. Available from: www.who.int/substance_abuse/activities/ en/WHODrugInjectionStudyOperations Manual.pdf. Accessed 21 July 2005.

16. Des Jarlais D, Friedman S, Perlis T on behalf of the World Health Organization. WHO Drug Injecting Study . Phase II. Operations manual version 3. New York, Geneva: NDRI/WHO; 1999.

17. Telles PR, Bastos FI, Guydish J, Inciardi JA, Surrat HL, Pearl M, et al. Risk behaviour and HIV seroprevalence among injecting drug users in Rio de Janeiro, Brazil. AIDS. 1997;11 (Suppl 1):S35-S42.

18. Guimarães ML, Bastos FI, Telles PR, GalvãoCastro B, Diaz RS, Bongertz V, et al. Retrovirus infections in a sample of injecting drug 
users in Rio de Janeiro City, Brazil: prevalence of HIV-1 subtypes, and co-infection with HTLV-I/II. J Clin Virol. 2001; 21(2):143-51.

19. Malta M, Carneiro-da-Cunha C, Kerrigan D, Strathdee SA, Monteiro. Case management of human immunodeficiency virus-infected injection drug users: a case study in Rio de Janeiro, Brazil. Clin Infect Dis. 2003;37 Suppl 5: S386-91.

20. Van Ness PH, Davis WR, Johnson BD. Socioeconomic marginality and health services utilization among Central Harlem substance users. Subst Use Misuse. 2004; 39(1):61-85.

21. Martelli CMT, Turchi MD, Souto FJD, SáezAlquézar A, Andrade ALSS, Zicker F. Anti$\mathrm{HBC}$ testing for blood donations in areas with intermediate hepatitis B endemicity. Rev Panam Salud Publica. 1999;6(1):69-73.

22. Souza CT, Bastos FI, Lowndes CM, Szwarcwald CL, dos Santos EM, De Castilho EA, et al. Perception of vulnerability to HIV infection in a cohort of homosexual/bisexual men in Rio de Janeiro, Brazil. Oswaldo Cruz Foundation STD/HIV Prevention Group. AIDS Care. 1999;11(5):567-79.

23. Dolan K, Rutter S, Wodak AD. Prison-based syringe exchange programmes: a review of international research and development. Addiction. 2003:98(2):153-8.

24. Healey A, Knapp M, Marsden J, Gossop M, Stewart D. Criminal outcomes and costs of treatment services for injecting and noninjecting heroin users: evidence from a national prospective cohort survey. J Health Serv Res Policy. 2003;8(3):134-41

25. Weissenbacher M, Rossi D, Radulich G, SosaEstani S, Vila M, Vivas E, et al. High seroprevalence of bloodborne viruses among street-recruited injection drug users from Buenos Aires, Argentina. Clin Infect Dis. 2003, 37(Suppl 5):348-52.

26. Samuel MC, Doherty PM, Bulterys M, Jenison SA. Association between heroin use, needle sharing and tattoos received in prison with hepatitis $B$ and $C$ positivity among streetrecruited injecting drug users in New Mexico, USA. Epidemiol Infect. 2001;127:475-84.

27. Kuo I, Sherman SG, Thomas DL, Strathdee SA. Hepatitis $B$ virus infection and vaccination among young injection and non-injection drug users: missed opportunities to prevent infection. Drug Alcohol Depend. 2004;73:69-78.

28. Hacker MA, Friedman SR, Telles PR, Teixeira SL, Bongertz V, Morgado MG, et al. The role of "long-term" and "new injectors" in a declining HIV/AIDS epidemic in Rio de Janeiro, Brazil. Subst Use Misuse. 2005;40:99-123.

29. Bastos FI, Bongertz V, Teixeira SL, Morgado MG, Hacker MA. Is HIV/AIDS decreasing among Brazilian injection drug users? Recent findings and how to interpret them. Mem Inst Oswaldo Cruz. 2005;100(1):91-6.
30. Brazil, Ministry of Health (Ministério da Saúde, Brasil). Portaria [Directive] 2080/GM issued in October 31. Available from: www. grupoesperanca.org.br/portaria_2080.htm. Accessed 4 May 2005.

31. Mast EE, Williams IT, Alter MJ, Margolis HS. Hepatitis B vaccination of adolescent and adult high-risk groups in the United States. Vaccine. 1998;16:S27-S29.

32. Gunn RA, Murray PJ, Ackers ML, Hardison WGM, Margolis AHS. Screening for chronic hepatitis $B$ and $C$ virus infections in an urban sexually transmitted disease clinic: rationale for integrating services. Sex Transm Dis. 2001; 28(3):166-170.

33. Centers for Diseases Control and Prevention. Hepatitis B vaccination among high-risk adolescents and adults-San Diego, California, 1998-2001. MMWR. 51(28):618-621.

34. Rich JD, Ching CG, Lally MA, Gaitanis MM, Schwartzapfel B, Charuvastra A, et al. A review of the case for hepatitis $B$ vaccination of high-risk adults. Am J Med. 2003;114:316-18.

Manuscript received on 27 September 2004. Revised version accepted for publication on 11 May 2005

RESUMEN Objetivos. Calcular las tasas de infección por el virus de la hepatitis B (VHB) en usuarios de drogas inyectadas en Río de Janeiro, Brasil, y dar a conocer sus conocimientos y actitudes en torno a la hepatitis y a la vacunación contra el VHB.

Ventana de oportunidad: reducción de las tasas de infección por el virus de la hepatitis B entre usuarios de drogas inyectadas en Río de Janeiro, Brasil, y planes futuros en torno a la vacunación contra la hepatitis B

Métodos. Seiscientos nueve usuarios de drogas que se reclutaron en Río de Janeiro entre 1999 y 2001 respondieron a un cuestionario y fueron sometidos a pruebas para detectar la presencia de hepatitis B y de otras infecciones transmitidas por la sangre. Las preguntas versaban sobre aspectos sociodemográficos, el consumo de alcohol y de drogas ilícitas, el modo de inyección de las drogas y las prácticas sexuales, los antecedentes médicos y los conocimientos sobre el VIH, el sida y la hepatitis viral.

Resultados. La prevalencia de infección por el VHB fue de 27,1\%;3,4\% de la muestra tuvo resultados positivos al $\mathrm{HB}_{\mathrm{s}} \mathrm{Ag}$ (infección activa) y $0,8 \%$ a anticuerpos anti$\mathrm{HB}_{\mathrm{s}}$ (indicadores de que ya se ha recibido la vacuna contra el VHB). La mayor parte de las personas entrevistadas afirmaron no haber sido vacunadas contra la hepatitis B, pero casi todos las que no habían recibido la vacuna $(97,8 \%)$ manifestaron estar dispuestas a vacunarse si se elaborase una vacuna.

Conclusiones. Pocos de los usuarios de drogas inyectadas habían sido vacunados contra el VHB. Aunque la mayor parte eran conscientes de los peligros que acarrea la hepatitis viral, ello raras veces se traducía en un cambio conductual invariable. La disposición de los participantes a vacunarse contra el VHB indica que si se implementase la vacunación en esta población se lograría reducir las tasas de hepatitis B.

Palabras clave Brasil, virus de la hepatitis B, drogadicción, drogas ilícitas. 